\title{
Welcome by the Editor-in-Chief
}

The English special issues of the journal of social sciences Polgári Szemle endeavour to provide scholarly assessments of economic and social developments in Hungary and of the country's history, and to explore its relationship to the rest of the world, with special focus on European identity and our relations with the European Union. For this reason the editorial board has rightly placed a study penned by academician Gábor Hamza about Robert Schuman's intellectual oeuvre and relations with Hungary first in this 3rd English special issue in Volume 15.

Gábor Hamza

\section{The Political and Intellectual Legacy of Robert Schuman, the "Father" of European Integration - with an Outlook on His Relations with Hungary}

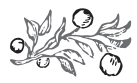

Summary

The essay gives a brief outline of the milestones in Robert Schuman's life and eventful political career. The purpose of Robert Schuman's activity was the restoration and reinforcement of peace between peoples and nations. Some of his views remains relevant today. The study shows his intellectual oeuvre and relations with Hungary.

Keywords: Robert Schuman, Europe, Hungary, European Community, Schumann Plan, Schuman Declaration, Jean Monnet, integration

Dr IUR. DDR H.c. GÁbor Hamza, University Professor, Eötvös Loránd University Budapest, full member of the Hungarian Academy of Sciences (gabor.hamza@ ajk.elte.hu). 
Gábor Hamza: The Political and Intellectual Legacy of Robert Schuman, the "Father"...

\section{SGHUMAN'S LIFE AND ACTIVITY}

Robert Schuman, who had a prominent part in forging the European integration, was born on 29 June 1886 in Clausen, Luxembourg. It is worthy of mention that although Schuman was born in Luxembourg, he was a German citizen. This is because his father, Jean-Pierre Schuman, who was born in Évrange, Lorraine, obtained German citizenship in 1871, after the cession of Alsace-Lorraine to Germany (and the change of its name to Reichsland Elsass-Lothringen). Robert Schuman became a French citizen in 1919, after World War I and subsequently to the conclusion of the Treaty of Versailles.

The prominent participant of French political life over several decades, Robert Schuman, who delivered his historic declaration inspired and elaborated by Jean Monnet, on the re-commencement of Europe (Déclaration du 9 mai 1950, also called the "Schuman Plan") in the famous Salon de l'Horloge at the Quai d'Orsay at the French Ministry of Foreign Affairs on 9 May 1950, had close ties with Hungary in the period between the two World Wars. In the first part of this essay, a brief outline is given of the milestones in Robert Schuman's life and eventful political career ("cursus honorum").

Robert Schuman started the secondary grammar school at the Athénée of the Grand Duchy of Luxembourg, and continued his studies at the Imperial Secondary Grammar School (Reichsgymnasium) of Metz, where he graduated in 1904. During the next few years he studies law, economic policy, theology, national and global economics and finances at various universities in Bonn, Munich, Berlin and finally in Strasbourg. In 1910 he served as an intern in Metz and in the same year his doctorate was also awarded summa cum laude. It is also important to note that his mother died in an accident in 1911.

The young Schuman seriously entertained the idea of becoming a priest, but an old family friend advised him against. After his second in 1912, he attended a meeting in the Benedictine monastery of Beuron. At that time, Willibrord Benzler (1853-1921), the Bishop of Metz established a group of young intellectuals with the aim to renew the liturgy. In addition to Robert Schuman, this group included Heinrich Brüning (1885-1970), subsequent imperial Chancellor, and the well-known and highly respected theologian Franz Xaver Münch (1883-1940).

Until his death Robert Schuman remained a member of the Görres Society (GörresGesellschaft), which was established in January 1876 with the aim to eliminate the subordination or marginalisation of German Catholics in academic fields. In 1913, Bishop Benzler requested Schuman to undertake the role of president for Catholic youth associations. Joined by two hundred volunteers, in that year he organised a meeting of German Catholics in Metz.

During World War I, between 1914 and 1918, Schuman provided civil service in the administration of the Boulay district headquarters. His duty was primarily to oversee formerly French-owned goods expropriated by Germans. In 1918, after the retreat of German troops, he became member of the Metz city council, which clearly shows 
that after the re-annexation of the region and the change of imperial rule, he had the confidence of the French authorities.

In 1919 he was elected member of House of Representatives the for the Lorrain Republican Union. In the interwar period, in 1944 Robert Schuman was a member of the Parti Démocrate Populaire (PDP), the predecessor of the Christian democratic party subsequently re-established as the Mouvement Républicain Populaire (Popular Republican Movement). He could fulfil his mandate as a representative up to August 1940. The Parti Démocrate Populaire published its theoretical journal Politique once in three months, in a relatively low number of copies, but well-known and highly regarded by intellectuals, and Robert Schuman was among its committed, proactive staff members. However, this undoubtedly highly important activity of his still needs to be explored and analysed for assessment.

In May 1940, after the outbreak of World War II, he served as State Secretary for Refugees jointly with Charles de Gaulle. When France capitulated, in June 1940, he refused the ministerial post offered by Prime Minister and Marshal Philippe Pétain. In August 1940 Robert Schuman was arrested by the Gestapo in Paris, as his cooperation with the National Socialist Germany could not be won. He was the very first Member of Parliament imprisoned by the Gestapo.

His arrest was to a great extent also due to the fact that he had maintained good relations with Kurt von Schuschnig (1897-1977), the Chancellor of the Republic of Austria before the Anschluss, who was also compelled to spend several years in the concentration camps of the National Socialist Germany (NS-Staat), under circumstances that were difficult and humiliating, but still considerably privileged.

After his detention, Robert Schuman was first expelled from Lorraine, and then deported to Neustadt on the Rhine, where he was kept in "special detention". In 1942 he managed to escape from this place. He found refuge first in St Martin's Benedictine monastery near Ligugé, then in a Trappist monastery, and finally in a Catholic orphanage. It is worth mentioning that the most important thing he had carried on him everywhere was his missal.

In 1945, the French Resistance accused Robert Schuman, wrongly and in the absence of evidence, of "unworthiness of the nation". However, the Lorraine electorate, and more specifically, the Thionwille District, elected him to the national assembly by a clear majority of the votes, and he presided the financial committee of substantial powers. He undertook to serve as a minister on several occasions in frequently changed governments of the 4th French Republic (Quatrième République). Between 1946 and 1947 he was a Finance Minister, and on 23 November 1947 he became the Prime Minister.

His position of high responsibility as head of government ended in 1948. He was compelled to resign as a result of the grave, nearly irresolvable economic and political problems. As a Prime Minister, he exhibited exemplary perseverance in protecting France from both rightist and leftist extremities to prevent disintegration and to contribute to improving and cementing citizens' confidence in democracy. Between 1948 and 1952, he acted as foreign minister for eight short-term governments. During this 
period he secured continuity in France's foreign policy, consciously steering the state toward a new path (nouveau chemin) of a "European profile".

When the European Coal and Steel Community was established by the Treaty of Paris, aimed primarily at eliminating hostility between France and Germany was signed (on 18 April 1951), Robert Schuman served as foreign minister. The Treaty of Paris provides a highly centralised and detailed regulation of coal and steel production in the six member states. In legal terms, this treaty was a traité-loi, or law-making treaty, known in French law.

In his capacity as foreign minister, on 26 May 1952 Schuman signed the Deutschlandvertrag in Bonn, which settled relationships between France and the Federal Republic of Germany, on the one hand, and France and the United Kingdom (represented by Robert Anthony Eden [1897-1977] as Foreign Secretary) and the United States of America (represented by Secretary of State Dean Gooderham Achison [1893-1971]), on the other. In 1955 and 1956, Robert Schuman had another prominent position in French political life as minister of justice (garde des sceaux).

During the conclusion of the treaties signed in Rome on 25 March 1957 to establish the European Economic Community and the European Atomic Energy Community (EURATOM), he no longer had a position in government. On behalf of France, these treaties were signed by Christian Pineau (1904-1995) and Maurice Faure (19222014), both members of Guy Mollet's government.

It is well-known that the Schuman Plan, meant to implement the (partial) integration of Europe, had been masterminded by Jean Monnet, whose concept had a decisive impact on Robert Schuman. However, it is less known that the term "community" comes from Carl Friedrich Ophüls (1895-1970), who was later on the very first ambassador of the Federal Republic of Germany in Brussels. Note that Ophüls was a disciple of economist and philosopher Ferdinand Tönnies (1855-1936), who was influenced by the views of Max Weber (1864-1920). The first president of the Commission, Walter Hallstein (1901-1982) had studied from Carl Friedrich Ophüls.

At that time, the French public did not yet unanimously support Robert Schuman's ideas about the European Community (or Communities). This explains why the majority of the members in the French national assembly received the various drafts about a "European defence community" and a "European political community" drafted with Schuman's substantial contribution. In 1952 he had to give up his position as foreign minister. Nevertheless, Robert Schuman's political vision of a new Europe became increasingly known and accepted, and gradually made its way towards implementation.

Between 1953 and 1958, Robert Schuman truly exerted himself in establishing the European integration. He tirelessly popularised his ideas about the continent in a specific form at numerous lectures delivered in the countries of Western Europe. In 1958 Schuman was elected president of the Common Assembly of 78 members, an advisory body to the European Coal and Steel Community, which was seated in Strasbourg and may be considered as the predecessor of the European Parliament. He held this office up to 1960 . Once his presidential mandate expired, he remained a member of the Common Assembly up to February 1963. By a unanimous vote, the 
assembly assured Robert Schuman of its recognition of his outstanding achievements made as "father of Europe".

In 1958, Schuman was awarded the Karlspreis, handed over to him in Aachen. In 1959, jointly with Karl Jaspers (1893-1969), he was awarded the Erasmus Prize representing high international recognition.

Robert Schuman died on 4 September 1963, at the age of 77, in Scy-Chazelles near Metz.

The purpose of Robert Schuman's activity was the restoration and reinforcement of peace between peoples and nations. "People should make friends with you and this friendship will unite our countries" - wrote Federal Chancellor Konrad Adenauer (1876-1967) to him in 1962. The "European Community" is a work of peace born in his soul, which renders war impossible between two nations that had been enemies for centuries. This peace is also an example for the other regions of the world. "A united Europe is the harbinger of future universal solidarity," wrote Schuman in 1960. A world re-organised this way considerably facilitates peace and solidarity between rich and poor countries and peoples, overall disarmament and the protection and preservation of the economic achievements.

In his famous speech delivered on 9 May 1950, he considered it important to highlight that "Europe cannot be built in a day, neither as part of a plan based on some absolute priority; Europe will be realised through practical results, one step of which lies in setting a common goal." However, this common goal is not linked to the world of ideas. This is proven by the fact that two of the three treaties establishing the European Communities cover specific areas, namely, coal and steel production and nuclear energy generation. The speech known as the Schuman Declaration has not lost of its significance and timelines during the decades since it was voiced. In 1985, the commission presided by Jacques Delors rightly set 9 May, the date of delivering the Schuman Declaration, as Europe's Day.

\section{SCHUMAN'S RELATIONSHIP WITH HUNGARY}

Robert Schuman's interest and political activity was not confined to Western Europe. One of the highly significant evidences for this is that he visited Hungary three times, and this can be considered as his special attention to and obvious interest in Hungary. He made his first visit to Budapest in August 1930. In 1934 and 1935 he paid a severalday visit in the company of pro-Hungarian members of the French National Assembly and journalists. During his 1934 stay in Budapest, the Pál Almássy, Speaker of the House of Representatives entertained the French MP's for lunch. In the Budapest headquarters of the National Radical Party, the French representatives and journalists also visited journalist and politician Endre Bajcsy-Zsilinszky, subsequently an important voice against German expansion. A detailed report is given of this meeting in the 27 May 1934 issue of the paper Szabadság ("Freedom").

During the visit, Pierre Baudouin-Bugnet, Chairman of the French National Assembly's Committee for Central Europe and a member the visiting group that also in- 
cluded a senator, emphasised the need for cooperation. The visit also received highly favourable publicity in the contemporary French media. André Nicolas, a journalist who also participated in the group, stressed the significance of mutual understanding between Hungarians and the French in the prestigious journal Frontières. In September 1935, Robert Schuman and his fellow MP's by invitation of the Confederation of Hungarian Industrialists, the Hungarian National Economic Association and the daily Pesti Hirlap. The delegation also included Ernest Pezet, author of the high-profile book entitled "La Yougoslavie en péril" ("Yugoslavia in Peril"), published in 1933, who visited Hungary on no less than five occasions, and wrote about it with exceptional sympathy in his books and articles published in various widely read papers.

In addition to Hungary, Robert Schuman was also deeply interested in Austria, which was highly resented for political and ideological reasons by national socialists, especially after the Anschluss that took place in March 1938. This was the primary reason for the above-mentioned fact that after the German occupation of the northern part of France, in August 1940 the Gestapo arrested Schuman and kept him in detention for several months.

Special mention needs to be made of the profound influence a 1938 work entitled "Lutte pour la civilisation et philosophie de la Paix" (Fight for civilisation and for the philosophy of peace) by Maurice Blondel had on Robert Schuman, as it warned of the threat from the national socialist Germany (NS-Staat) to the Central European region and triggered quite a strong response at that time.

Robert Schuman's relationship with Hungary and the activity of the pro-Hungarian group in the French National Assembly between the two World Wars are still waiting for exploration and research. The study of this matter is by no means indifferent in our days, when Hungary is a full member of the European Union. Although indirectly, Robert Schuman had an outstanding role in the preparation for accession, as he considered the countries of Central Europe, including Hungary, as part of integrating Europe. It was not his fault that accession only took place with a more than fifty years' delay, on 1 May 2004.

\section{SCHUMAN'S VIEWS}

Robert Schuman considered the community of European states as a natural commercial community. Similarly in many respects to Francisco de Vitoria (1483/93-1546), the author of Relecciones Teologicas, who was active in the first half of the 16th century and is considered as one of the founders of modern international law, he considered this community based on commercial and economic relations as the natural expression of communicatio and societas. As his baseline, Schuman also presumes a kind of societas prefecta, which provides for the availability of all the means suitable for achieving the common goal, and in this particular case, for increasing European citizens' rights, prosperity (bonum commune) and intellectual riches. Quoting Francisco de Vitoria again, the community of European law and states is a kind of "totus orbis ... qui aliquo modo est una respublica". The bonum commune justifies, and moreover, requires the 
transfer of certain elements in the sovereignty of the individual states to the supranational European community. The coexistence of the various European nations is thus traced back to the moral rules built on and rooted in natural law, never forgetting that the community of European states is not merely based on economic factors.

In our opinion, Schuman's definition of democracy remains valid to this very date: "It (i.e. 'democracy' - the author) is at the service of people and works in agreement with it." Robert Schuman linked the concept of democracy to Christianity. In his view: "Democracy owes its existence to Christianity." However, he also recognises that democracy is easy to distort and may deform. He raises politicians' responsibility in his following warning: "Nothing is easier for political counterfeiters to exploit good principles for an illusion, and nothing is more disastrous than good principles that are badly applied." Unfortunately, this view of his remains relevant. The same applies to the election of the European Parliament, to be established on the basis of direct elections for the representation of the Member States' interests. In relation to this, he writes: "People (the European peoples) should be able to monitor and facilitate developments in the institutions of the European Community/Communities through their representatives specifically elected for this purpose (the members of the European Parliament). Thus, the members of the community's parliament need to be elected based on direct universal suffrage."

Robert Schuman was familiar with the works of Felicité Lamennais (1782-1854), one of the most significant persons in French Catholic liberalism. In his debates with the collectivist ("communist") ideologists of his age, Lamennais drafted the fundamental principles of Christian liberalism: "What is democracy? It is the full liberation of the individual, securing the totality of human rights, and full personal autonomy." Felicite Lamennais also included the freedom of speech and the freedom of the press in the totality of human rights. As he put it: "Only the freedom of speech provides a guarantee against dangerous words. Free debate is the only remedy to all spiritual aberrations."

As known, Christian liberalists built their ideas of freedoms on the belief that every human being is a sovereign entity and every human personality is from God the creator. With a view to this, they denied the extreme conflict that has evolved between the individual and the society and between individualism and collectivism in modern times (in the 19th, 20th and 21st centuries).

The personalist philosophers and thinkers who gathered around the journal Esprit, established by Emmanuel Mounier (1905-1950), endeavoured to find a way out of the trap of individualism and collectivism. Personalist thinking focussed on the dignity and freedom of the human personality ordered by God, thus they lent a transcendental perspective to liberalist teachings, and moreover, in an age when the ideas and utopias of collectivism were aggressively enforced. "Every person is created in the image of God, every person is called to the formation of one immense Body, mystical and physical, in the charity of Christ" - taught Emmanuel Mounier.

In addition to the freedom and dignity of the human personality, personalist philosophers also attached high significance to human solidarity and the gospel principle 
of love: in their opinion, the basis of social coexistence is not some kind of a violent collectivism, but solidarity and love. Schuman intended to create European unity on the basis of Emmanuel Mounier's above described complex teachings.

Robert Schuman emphasised on several occasions that Europe should be given a spirit (esprit). He puts it as follows: "This togetherness (of peoples) cannot and should not remain an economic and technical undertaking. It must be given a soul. Europe will not live and will not be saved except to the degree in which it has awareness of itself and of its responsibilities, when it returns to the Christian principles of solidarity and fraternity."

\section{REFERENGES}

Benzler, W. (1922): Erinnerungen aus meinem Leben. Beuron.

Braun, A. C. (1948): Erinnerungen an Franz Xaver Münch. Verlag Josef Habbel, Regensburg.

Brown Scott, J. (1934): The Spanish Origin of International Law. Francisco de Vitoria and His Law of Nations. Clarendon Press, Oxford.

Fejérdy, G. R. (2004) : Egy elfelejtett kapcsolat: Robert Schuman és Magyarország [The forgotten relationship between Robert Schuman and Hungary]. Valóság, Vol. 47, No. pp. 58-66.

Fejérdy, G. R. (2008): Les visites de Robert Schuman dans le bassin du Danube. In: Schirmann, S. (ed.): Robert Schuman et les pères de l'Europe. Cultures politiques et années de formation. Publications de la Maison de Robert Schuman. Etudes et travaux; 1., Peter Lang AG, Brussels, Bern, Berlin, pp. 69-84.

Fejérdy, G. R. (2015): Wizity Roberta Schumana w panstwah nadunajskich. In: Radwan, A. (ed.): Schuman i jego Europa. Polska Fundacja im. Roberta Schumana, Warsawa, pp. 54-67.

Hamza, G. (1999): A „Harmadik Birodalom” eszméje a német filozófiai és politikai gondolkodásban [The idea of the "Third Empire" in German philosophical and political thinking]. Magyar Tudomány, Vol. 44, No. 7, pp. 779-787.

Hamza, G. (2001): Die Idee des "Dritten Reichs" im deutschen philosophischen und politischen Denken des 20. Jahrhunderts. Zeitschrift der Savigny-Stiftung für Rechtsgeschichte (Germ. Abt.), Vol. 118, pp. 321-336.

Hamza, G. (2013): The Idea (Concept) of the "Third Reich" ("Drittes Reich") in the German Legal, Philosophical and Political Thinking in the 20th Century. The Western Australian Jurist, Vol. 4, pp. 255-272, https://walta.net.au/wajurist/vol4/the-idea-of-the-third-reich-drittes-reich-in-german-legal-philosophical-and-political-thinking-in-the-20th-century/.

Lejeune, R. (2000): Robert Schuman, père de l'Europe (1886-1963). La politique, chemin de sainteté. A. Fayard, Paris.

Nemessányi, Z. (2003): Robert Schuman élete [The life of Robert Schuman]. Európai Jog, Vol. 3, No. 1, pp. 37-40.

Schuman, R. (1990): Pour l'Europe. Editions Nagel Briquet, Genève.

Weiß, O. (2014): Kulturkatholizismus. Katholiken auf dem Weg in die deutsche Kultur 1900-1933. Friedrich Pustet Verlag, Regensburg. 